\title{
The Luteovirus P4 Movement Protein Is a Suppressor of Systemic RNA Silencing
}

\author{
Adriana F. Fusaro ${ }^{1,2,3}$, Deborah A. Barton ${ }^{1}$, Kenlee Nakasugi ${ }^{1}$, Craig Jackson ${ }^{1}$, \\ Melanie L. Kalischuk 1,4, Lawrence M. Kawchuk ${ }^{1,5}$, Maite F. S. Vaslin ${ }^{3}$, Regis L. Correa ${ }^{2,3, *}$ \\ and Peter M. Waterhouse ${ }^{1,2,6, *}$ \\ 1 School of Life and Environmental Sciences, University of Sydney, Sydney, NSW 2006, Australia; \\ adriana.fusaro1@gmail.com (A.F.F.); deborah.barton@sydney.edu.au (D.A.B.); \\ knakasugi@illumina.com (K.N.); craig.jackson@sydney.edu.au (C.J.); mkalischuk@ufl.edu (M.L.K.); \\ lawrence.kawchuk@agr.gc.ca (L.M.K.) \\ 2 Plant Industry Division, CSIRO, P.O. Box 1600, Canberra, ACT 2601, Australia \\ 3 Department of Virology (M.F.S.V.), Department of Genetics (R.L.C.) and Institute of Medical \\ Biochemistry (A.F.F.), Federal University of Rio de Janeiro (UFRJ), Rio de Janeiro 21941-590, Brazil; \\ maite@micro.ufrj.br \\ 4 North Florida Research and Education Center, University of Florida, Quincy, FL 32351, USA \\ 5 Department of Agriculture and Agri-Food Canada, Lethbridge, AB T1J4B1, Canada \\ 6 School of Earth, Environmental and Biological sciences, Queensland University of Technology, Brisbane, \\ QLD 4001, Australia \\ * Correspondence: regis@biologia.ufrj.br (R.L.C.); peter.waterhouse@qut.edu.au (P.M.W.); \\ Tel.: +61-7-3138-7793 (R.L.C. \& P.M.W.)
}

Received: 25 September 2017; Accepted: 6 October 2017; Published: 10 October 2017

\begin{abstract}
The plant viral family Luteoviridae is divided into three genera: Luteovirus, Polerovirus and Enamovirus. Without assistance from another virus, members of the family are confined to the cells of the host plant's vascular system. The first open reading frame (ORF) of poleroviruses and enamoviruses encodes P0 proteins which act as silencing suppressor proteins (VSRs) against the plant's viral defense-mediating RNA silencing machinery. Luteoviruses, such as barley yellow dwarf virus-PAV (BYDV-PAV), however, have no P0 to carry out the VSR role, so we investigated whether other proteins or RNAs encoded by BYDV-PAV confer protection against the plant's silencing machinery. Deep-sequencing of small RNAs from plants infected with BYDV-PAV revealed that the virus is subjected to RNA silencing in the phloem tissues and there was no evidence of protection afforded by a possible decoy effect of the highly abundant subgenomic RNA3. However, analysis of VSR activity among the BYDV-PAV ORFs revealed systemic silencing suppression by the P4 movement protein, and a similar, but weaker, activity by P6. The closely related BYDV-PAS P4, but not the polerovirus potato leafroll virus $\mathrm{P} 4$, also displayed systemic VSR activity. Both luteovirus and the polerovirus $\mathrm{P} 4$ proteins also showed transient, weak local silencing suppression. This suggests that systemic silencing suppression is the principal mechanism by which the luteoviruses BYDV-PAV and BYDV-PAS minimize the effects of the plant's anti-viral defense.
\end{abstract}

Keywords: Luteoviridae; Luteovirus; Polerovirus; RNA silencing suppression

\section{Introduction}

Plants fight against viral infection with their intrinsic RNA degradation mechanism, often termed the RNA silencing machinery [1]. In Arabidopsis thaliana, virus-derived double-stranded RNA (dsRNA) molecules are targeted by RNase III-family DICER-LIKE (DCL) proteins, generating 21 to 24 nucleotide (nt)-long small interfering RNAs (siRNAs) [2-4]. Most RNA viruses are preferentially degraded by the DCL4 protein, which explains the greater accumulation of 21-nt siRNAs in most of the plants analyzed 
so far [5]. DCL2- and DCL3-produced siRNAs of 22 and $24 \mathrm{nt}$, respectively, may also play important antiviral roles $[2-4,6,7]$. Virus-derived siRNAs of all size classes guide distinct ARGONAUTE (AGO) proteins to single-stranded RNA molecules, promoting their destabilization [8]. The efficiency of this antiviral defense system is also largely dependent on a siRNA amplification step promoted by host RNA-dependent RNA polymerases (RDRs). Following AGO-mediated cleavage, RDRs, in particular RDR1 and RDR6, use target viral RNAs to make new dsRNA molecules which are, in turn, also processed by DCLs, generating secondary virus-derived siRNAs [6,9]. Secondary siRNAs may presumably act as systemic silencing signals, priming antiviral responses in uninfected cells [10]. Some viruses, on the other hand, are able to counteract this defense system by expressing proteins that act as viral suppressors of RNA silencing (VSRs). Two major strategies used by VSRs are known: inhibiting the production or accumulation of locally-acting siRNAs in the infected tissue (local suppression) or preventing the spread of silencing signals to systemic leaves (systemic silencing suppression) [11]. Some VSRs bind to the siRNAs directing the silencing machinery (e.g., tombusvirus P19) [12], while others target one or several proteins of the RNA silencing pathway, like ARGONAUTE1 (AGO1) (targeted by cucumovirus 2b) [13], DCL4 (targeted by carmovirus P38) [3] and DRB4 (targeted by caulimovirus P6) [14].

The members of the family Luteoviridae (luteovirids) are divided into three genera: Luteovirus, Polerovirus and Enamovirus. They are transmitted by aphids in a persistent manner, and are restricted to the phloem tissue where a number of them cause cell necrosis. Their single stranded RNA genomes each contain 5-6 major open reading frames (ORFs) and produce subgenomic RNAs as part of their gene expression strategy (Figure 1A). There is clear sequence conservation in ORFs 3,4 and 5 among all of the family members. The major capsid protein is encoded by ORF 3 [15,16], and ORF 4 , which is absent in the enamovirus pea enation mosaic virus-1 (PeMV-1), encodes a cell-to-cell movement protein [17]. A small ORF upstream of ORF 3, named ORF 3a, was recently discovered in luteovirids and its corresponding P3a protein is involved in systemic virus movement in the polerovirus turnip yellows virus, with a possible role in cap-independent translation in luteoviruses [18]. The protein generated by translational readthrough from ORF 3 into ORF 5 is required for efficient aphid transmission [19]. There is considerable sequence diversity in the 5' portion of the genomes (ORFs 0,1 and 2) of the luteovirids, but the P0 proteins, encoded by ORF 0 of the poleroviruses and enamovirus, have the conserved function of being VSRs that target AGO1 for degradation [11,20].

Luteoviruses, such as barley yellow dwarf virus-PAV (BYDV-PAV), have no P0 to carry out the VSR role, so we investigated whether other proteins or RNAs encoded by BYDV-PAV confer protection against the plant's silencing machinery. We were unable to detect any evidence of protection afforded by a possible decoy effect of the highly abundant subgenomic RNA3, nor from proteins encoded by ORFs 1, 2, 3 or 5 . However, we detected a strong suppression of systemic silencing by P4 and a similar, but weaker, activity by P6. The BYDV-PAS P4, but not the polerovirus potato leafroll virus (PLRV) P4, also displayed a similar VSR activity. Both luteovirus and the polerovirus P4 proteins also showed transient, weak local silencing suppression. Transient expression of luteovirus P4 in Nicotiana benthamiana triggered dose-dependent cell necrosis which increased over time, but it did not inhibit P4's systemic VSR activity against the propagation and spread of anti-viral siRNAs, nor did it prevent the replication and egress of potato virus $\mathrm{X}(\mathrm{PVX})$. This suggests that systemic silencing suppression is the principal mechanism by which the luteoviruses BYDV-PAV and BYDV-PAS minimize the effects of the plant's anti-viral defense.

\section{Materials and Methods}

\subsection{Sequence Analysis}

The accession numbers of amino acid sequences used in multiple alignments were obtained from NCBI and are as follows: barley yellow dwarf virus-PAV (NC_004750) containing protein coding sequences NP_840067, NP_840014, NP_840015, NP_840016, NP_840017, NP_840018; pea 
enation mosaic virus (NC_003629) containing protein coding sequences NP_619735, NP_620026, NP_619736, NP_620027, NP_619738; beet western yellows virus P0, NP_840095; cucurbit aphid-borne yellows virus P0, NP_620100; cereal yellow dwarf virus-RPV P0, NP_840020; potato leafroll virus P0, NP_056746; sugarcane yellow leaf virus P0, NP_050005; cocksfoot mottle virus P1, NP_941375; rice yellow mottle virus P1, NP_041737; southern bean mosaic virus P1, NP_660270; cymbidium ringspot virus P19, CAA33535; turnip crinkle virus P38, NP_620723; tobacco etch virus HCPro, AAA47910; cucumber mosaic virus 2b, AEB39608; BYDV-PAS P4, AAF26426.1; PLRV P4, D13953.1; BYDV-GAV P4, AAO65189.1; BYDV-PAV P6, APD77443.1; BYDV-GAV P6, AAO65190.1; BYDV-PAV isolate 064 P6, ABP68814.1; BYDV-PAV isolate 047 P6, ABP68742.1; BYDV-PAV isolate 048 P6, ABP68754.1; BYDV-PAV isolate 052 P6, ABP68760.1; BYDV-PAV isolate 05GG6 P6, ABY73569.1; BYDV-PAV isolate 04ZZ5 P6, ABY73551.1. Multiple sequence alignments using default parameters and percent identities were calculated using ClustalX 2.0.12 [21]. Phylogenetic analyses were conducted using MEGA version 5.0 [22]. Consensus phylogenetic trees were constructed by the neighbour-joining method with pairwise deletion and bootstrap with 1000 replications.

\subsection{Small RNA Deep Sequencing and Bioinformatic Analyses}

Total RNA was extracted from barley plants infected with BYDV-PAV using the miRNeasy kit (Qiagen, Hilden, Germany), according to the manufacturer's instructions. BYDV-PAV small RNA library was prepared (Illumina small RNA sample preparation kit, Illumina, San Diego, CA, USA) and deep sequenced on the Illumina GAIIx platform (Illumina, San Diego, CA, USA) according to the manufacturer's protocols. Deep sequencing reads were preprocessed (read quality assessment, adapter removal, read size extraction) utilizing the Fastx Toolkit set of scripts (http://hannonlab.cshl. edu/fastx_toolkit/index.html) and in-house custom perl scripts. Small RNA reads between 21 and 24 nt were mapped to the BYDV-PAV reference genome using Bowtie v0.12.7 [23], with no mismatches allowed. Read distribution profile visualization and coverage analyses were performed utilizing custom perl scripts, mpileup from SAMtools [24], and the OpenOffice (in Ubuntu Linux) spreadsheet application. For comparisons of read distribution profiles, reads were normalized against the total read count (after preprocessing) per 10 million reads, and plotted as number of reads per base.

\subsection{DNA Constructs}

Constructs pBin-35S-mGFP5 [25], pJL3:P19 [26], L6MHV encoding an autoactive allele of the flax L6 rust resistance gene [27], and PVX-GFP, $\mathrm{P0}{ }^{\mathrm{PL}}, \mathrm{P0}^{\mathrm{CY}}$ and $\mathrm{P} 1^{\mathrm{RY}}$ [20] were described previously. Binary vector pPTN253 encoding CED-9 from Caenorhabditis elegans [28] driven by the 35S cauliflower mosaic virus (CaMV) promoter was a gift by James Dale (QUT, Australia).

The cDNA of ORFs of BYDV-PAV P1-P2 (NP_840014), P2 (NP_840067), P3 (NP_840015), P4 (NP_840016), P3-P5 (NP_840017) were synthesized by GENEART (Regensburg, Germany) and transferred from the pUC vector to the CaMV 35S-expression cassette in the pART7 vector [29]. Each 35S-expression cassette was then transferred as a NotI fragment into the binary vector pBART. For the analysis of different P4 proteins and P6, the cDNA of ORFs of BYDV-PAV P4 (NP_840016), PLRV P4 (D13953.1) and BYDV-PAV P6 (APD77443.1) were PCR-amplified with primers that introduced a HindIII site at the $5^{\prime}$ end and an XbaI site at the $3^{\prime}$ end of each ORF.

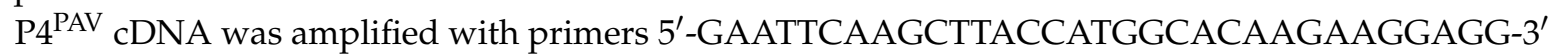
(forward) and 5'-GAATTCTCTAGACTATCGTTGATTCCTGGA-3' (reverse); P4 ${ }^{\text {PL }}$ cDNA was amplified with primers 5'-GAATTCAAGCTTACCATGTCAATGGTGGTGCAC-3' (forward) and 5'-GAATTCTCTAGATCATCCGCGCTTGATAG-3' (reverse), and P6 ${ }^{\text {PAV }}$ cDNA was amplified with primers 5'-GAATTCAAGCTTATGGATGACCTCCACGTTATC-3' (forward) and 5'-GAATTCTCT AGATTAAACAGAAGAGCGGAAGGAG-3' (reverse). Following digestion of PCR products, each ORF was cloned as a HindIII-XbaI fragment directly into the pORE1 binary expression vector [30] containing a CaMV 35S expression cassette, generating constructs pORE1-35S::PAV4, pORE1-35S::PAV6 and pORE1-35S::PLRV4. The cDNA of BYDV-PAS P4 (AAF26426.1) was synthesized and cloned into 
a pUC plasmid by GENEART (Regensburg, Germany) with unique HindIII and XbaI sites as $5^{\prime}$ and $3^{\prime}$ flanking sequences, respectively. Following plasmid digestion, the HindIII-XbaI fragment corresponding to the $\mathrm{P} 4{ }^{\mathrm{PAS}} \mathrm{ORF}$ was ligated into the pORE1 binary vector (mentioned above) to generate pORE1-35S::PAS4.

\subsection{Transient Expression Assay in N. benthamiana}

Transgenic N. benthamiana (line 16c), which is homozygous for the GFP transgene [25], and the Agrobacterium infiltration method have been described previously [31]. For co-infiltrations of wild-type $N$. benthamiana or line 16c, cultures of A. tumefaciens (strain GV3101) harboring a relevant binary plasmid, were mixed before infiltration to a final $\mathrm{OD}_{600}=0.5$ each, except for L6 and CED-9 $\left(\mathrm{OD}_{600}=1\right)$. Dilutions of $\mathrm{P} 4{ }^{\mathrm{PAV}}, \mathrm{P}^{\mathrm{PAS}}$ and $\mathrm{P}^{\mathrm{PL}}$ were obtained by adding appropriate concentrations of a vector-less Agrobacterium culture to the infiltrate solutions. The GFP fluorescence was monitored with a hand-held UV lamp as previously described [31]. Pictures (UV and visible light) were taken with a Canon EOS 550D digital camera (Canon, Tokyo, Japan).

\subsection{RNA Blot Analysis}

Total RNA was extracted from agroinfiltrated leaves of $N$. benthamiana $16 \mathrm{c}$ collected at $6 \mathrm{dpi}$, with TRIzol reagent (Invitrogen, Carlsbad, CA, USA). The manufacturer's protocol was modified as an additional phenol:chloroform wash was added before an overnight precipitation step at $-20^{\circ} \mathrm{C}$. For high and low molecular weight Northern blots, $20 \mu \mathrm{g}$ and $40 \mu \mathrm{g}$ of total RNAs were loaded and run on formaldehyde and polyacrylamide gels, respectively. RNA detection and hybridization conditions were previously described [20].

\section{Results}

\subsection{BYDV-PAV Elicits an RNA Silencing Response in the Phloem}

BYDV-PAV is known to circularize its RNA for cap-independent translation of its genome [32]. It also produces a highly abundant non-coding sgRNA3 (Figure 1B) [33]. We wondered if, in the absence of a P0 VSR, these attributes might in some way protect BYDV-PAV against the plant's anti-viral RNA degradation system in the phloem. Therefore, we examined the small RNA (sRNA) profiles of virus-infected plants. Total RNA from BYDV-PAV-infected barley was extracted, size-fractionated, and the sRNAs sequenced using an Illumina machine. The predominant class of sRNAs, identical or complementary in sequence to the BYDV-PAV genome, was $22 \mathrm{nt}$ (502k reads) with less abundant $21 \mathrm{nt}$ (328k reads) and $24 \mathrm{nt}$ (146k reads) size classes (Figure 1C). This profile of abundant siRNAs (representing $9.76 \%$ of total sRNAs) shows that the silencing machinery in phloem tissues mounts a response to BYDV-PAV infection, suggesting that circularization of BYDV-PAV genomic RNA for translation does not strongly inhibit this process, as shown for other viruses (e.g., [34]). Despite the abundance of sgRNA3, which might have acted as a decoy to saturate the plant's silencing machinery and thereby protect the viral genome from degradation, there did not appear to be a predominance of siRNAs from this region, suggesting that BYDV-PAV employs a different silencing suppression or avoidance strategy. 


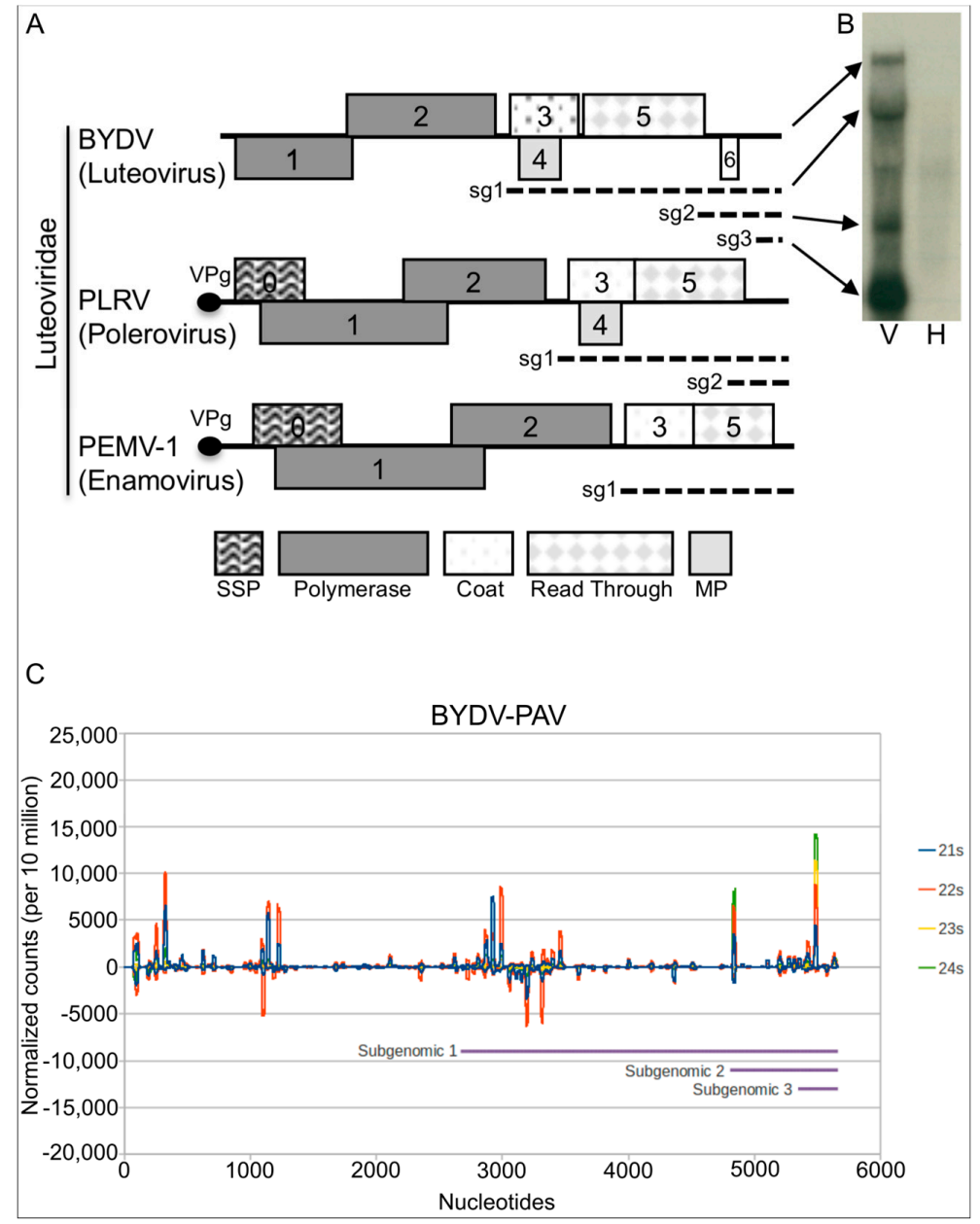

Figure 1. Genome organization of the family Luteoviridae and mapping of perfect match 21 to 24 nt virus-derived small RNAs from barley yellow dwarf virus-PAV (BYDV-PAV)-infected plants. (A) Genome organization of viruses belonging to the three genera of the family Luteoviridae. Numbers within rectangles indicate known luteovirid ORFs: silencing suppressor protein (VSR), polymerase, coat-protein, read-through transmission protein and movement protein (MP). Subgenomic RNAs (sg1, sg2 and sg3) are represented as dotted lines. (B) Northern blot from virus-infected (V) and healthy (H) plants showing the accumulation of genomic and subgenomic BYDV-PAV RNAs (reproduction from Kelly et al. 1994 [33]). (C) Profiles of 21 to $24 \mathrm{nt}$ size reads mapping to the BYDV-PAV genome deep-sequenced from barley-infected plants. Profile is shown as a cumulative number of reads per nucleotide, normalized to the total library size per 10 million reads. Reads that aligned to the negative strand are plotted as negative Y-axis values. Purple bars show the sub-genomic RNA regions (positions starting at 2678, 4817 and 5356). 'Hot-spots' or peaks of read counts can be seen across the genome.

\subsection{Assaying BYDV-PAV-Encoded Proteins for Silencing Suppressor Activity}

In an attempt to identify potential VSR candidates in BYDV-PAV, we compared its ORF sequences with those of known suppressors, including rice yellow mottle virus (RYMV) P1, tomato bushy stunt virus (TBSV) P19, turnip crinkle virus (TCV) P38, cucumber mosaic virus (CMV) 2b, potato virus $Y$ (PVY) HCPro and five P0s (data not shown). We also compared the translated ORF sequences using TBLASTn and BLASTp against accessions in the NCBI plant viral database containing the keyword "suppressor". Neither analysis produced any obvious VSR ortholog for any of the six BYDV ORFs. Therefore, the proteins P1-2, P2, P3, P4, P3-5 and P6 encoded by the BYDV-PAV genome were tested for local and systemic VSR activity using the 16c system [35]. The virus genes were placed under the control of the $35 \mathrm{~S}$ promoter in binary vectors and transiently co-expressed with a sense GFP 
transgene (sGFP) in fully-expanded leaves of N. benthamiana line 16c. This line has an integrated GFP transgene [25,31] and is a well stablished assay for detecting suppression activity, as a bright green fluorescent tissue is observed under the UV light 3-7 days post infiltration (dpi) if the candidate protein is able to block the locally-induced silencing triggered by the sGFP transgene. If the co-infiltrated virus gene has no systemic VSR activity, the infiltrated tissue emits a signal that spreads through the phloem and emerges in the apex and young leaves of the plant to silence the GFP; co-infiltration with a systemic VSR delays or negates the emergence of distal silencing. The percentage of plants that fail to show distal silencing after $2-3$ weeks is taken as a measure of the candidate genes' systemic VSR activity [36].

Using this system and the well-described local VSR, P19, from TBSV as a control, BYDV-PAV P1-2, P2, P3, P3-5 and P6 showed little or no evidence of local VSR activity at 6 dpi (Figure 2A), even when multiple proteins were co-expressed (data not shown). This contrasts with a report that P6 from BYDV-GAV has local VSR activity [37], but this may be due to the marked sequence divergence of GAV from other BYDV isolates, especially in the P6 ORF sequence (Figure S1). BYDV-PAV P4 (P4 ${ }^{\mathrm{PAV}}$ ), however, showed a weak, transient local VSR activity that could be detected through a mild increase in GFP fluorescence when compared to control empty vector. Assessing the spread of the silencing signal from infiltrated spots at 14 dpi revealed that $\mathrm{P} 4^{\mathrm{PAV}}$ and BYDV-PAV $\mathrm{P} 6\left(\mathrm{P}^{\mathrm{PAV}}\right)$ produce strong and moderate systemic silencing suppression, respectively, when compared to the well-known systemic VSR P1 from RYMV (P1 ${ }^{\mathrm{RY}}$ ) (Figure 2B-D). The spread of the silencing signal was detected in only $20 \%$ of plants co-infiltrated with $\mathrm{P}^{\mathrm{PAV}}$, a profile of systemic VSR activity equivalent to that of $\mathrm{P} 1^{\mathrm{RY}}$, while $40 \%$ of plants showed systemic silencing when co-infiltrated with P $6^{\mathrm{PAV}}$. This same moderate systemic VSR activity has also been reported for BYDV-GAV P6 [37].

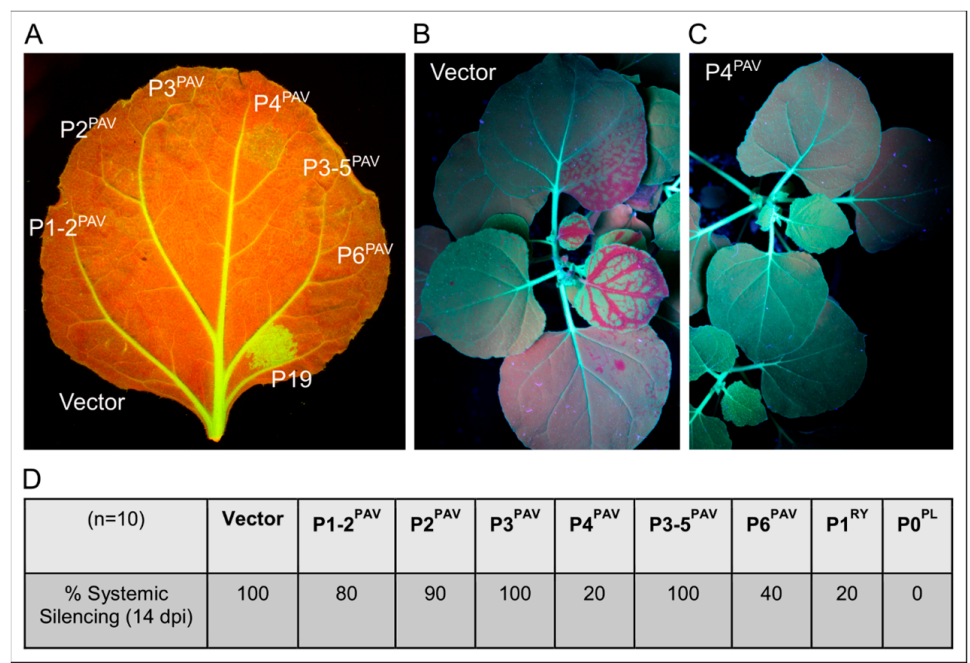

Figure 2. Local and systemic silencing suppression assays of luteovirus BYDV-PAV proteins. (A) Agro-infiltration of GFP-expressing N. benthamiana 16c leaves with sense GFP transgene plus BYDV-PAV proteins P1-2, P2, P3, P4, P3-5 or P6. The empty vector was used as a negative control for silencing suppression activity, while P19 from tomato bushy stunt virus (TBSV) was used as a positive control. Pictures were taken at 5 dpi under UV light. (B) Systemic silencing assay control. N. benthamiana 16c plants were agro-infiltrated with a sense GFP inducer plus the empty vector pBART. Picture of whole plants showing systemic silencing was taken at 14 dpi under UV light. (C) Systemic silencing assay for the BYDV-PAV P4 protein. N. benthamiana 16c plants were agro-infiltrated with a sense GFP inducer plus the P4 protein. Picture of whole plants showing no systemic silencing was taken at 14 dpi under UV light. (D) Scores of silencing suppression activity for the BYDV-PAV proteins P1-2, P2, P3, P4, P3-5 and P6. The P1 protein from RYMV and the P0 protein from PLRV were used as positive controls. 
When analyzing the short-distance spread of the silencing signal at $7 \mathrm{dpi}$, it became apparent that $\mathrm{P} 4{ }^{\mathrm{PAV}}$, but not $\mathrm{P}^{\mathrm{PAV}}$, reduces the development of the red "halo" (Figure $3 \mathrm{~A}$ ) which normally reports the initial cell-to-cell spread of the mobile silencing signal to adjacent cells outside the infiltrated area [38-40]. This result shows that the VSR activity by $\mathrm{P}^{\mathrm{PAV}}$ delays the cell-to-cell movement of the systemic silencing signal. This assay also showed that $\mathrm{P} 4{ }^{\mathrm{PAV}}$, but not $\mathrm{P} 6^{\mathrm{PAV}}$, induces necrosis of the infiltrated tissue, which, under the blue light used to excite GFP, gives a yellowish fluorescence making it difficult to visually assess the GFP expression. The necrosis induced by $\mathrm{P} 4{ }^{\mathrm{PAV}}$ could be largely prevented by adding a CED-9-encoding construct to the $\mathrm{P} 4^{\mathrm{PAV}}$ treatment (Figure 3A), since CED-9 is an antiapoptotic protein from C. elegans shown to suppress viral-induced necrosis in plants [41]. Inhibition of $\mathrm{P}^{\mathrm{PAV}}$-triggered necrosis by CED-9 did not impact on $\mathrm{P} 4{ }^{\mathrm{PAV}}$ VSR activity, since the delay of red halo formation at $7 \mathrm{dpi}$ or $11 \mathrm{dpi}$ (Figures $3 \mathrm{~A}$ and S2), or the strong suppression of systemic silencing by $\mathrm{P} 4{ }^{\mathrm{PAV}}$ (Figure $3 \mathrm{~B}$ ), remained unaffected in plants agro-infiltrated with a mix containing $\mathrm{P} 4{ }^{\mathrm{PAV}}$ and CED-9 constructs. These results suggest that the VSR activity by $\mathrm{P} 4{ }^{\mathrm{PAV}}$ and induction of necrosis are not linked.
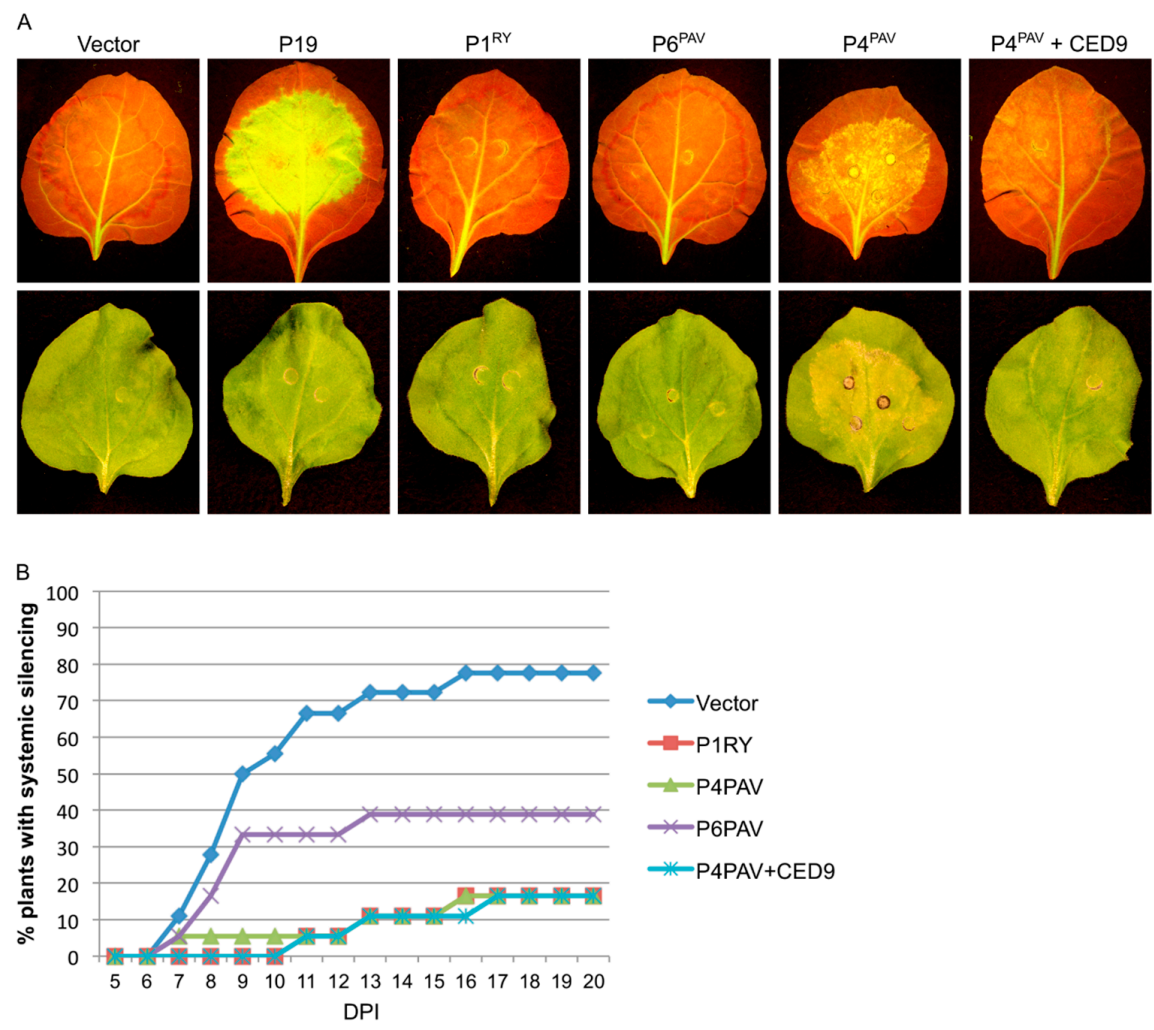

Figure 3. Inhibition of necrosis does not affect BYDV-PAV P4 local and systemic silencing suppression activities. (A) N. benthamiana 16c plants were agro-infiltrated with a sense GFP inducer plus the empty vector pBART, TBSV P19, RYMV P1 (P1 ${ }^{\mathrm{RY}}$ ) or the BYDV-PAV proteins $\mathrm{P} 6^{\mathrm{PAV}}$ or $\mathrm{P} 4^{\mathrm{PAV}}$. The $\mathrm{P} 4{ }^{\mathrm{PAV}}$ was also agro-infiltrated in the presence of the antiapoptotic protein CED-9 from C. elegans for inhibition of $\mathrm{P}^{\mathrm{PAV}}$-induced necrosis on the infiltrated tissue. The effects of the different suppressors on local cell-to-cell silencing spread can be analysed by the dynamics of the red halo formation around the infiltrated area. Pictures were taken at 7 dpi under UV (upper panel) or normal light (lower panel). (B) Plants $(n=18)$ infiltrated with the above constructs were scored for the appearance of systemic silencing at different days post-infiltration (DPI). 
3.3. Systemic Silencing Suppression and Necrosis Is Produced by P4 from Two Different Luteoviruses, but Not by $P 4$ from a Polerovirus

To explore whether P4 proteins in other luteoviruses and poleroviruses also have VSR activity, the appropriate ORF was cloned from BYDV-PAS (P4 $\left.{ }^{\mathrm{PAS}}\right)$ and from PLRV $\left(\mathrm{P} 4^{\mathrm{PL}}\right)$, and placed under the control of the CaMV 35 S promoter. Testing the constructs in the 16c system with the standard agro-inoculum strength of $0.5 \mathrm{OD}$ (Figure $4 \mathrm{~A}$ top and Figure $4 \mathrm{~B}$ ) showed that $\mathrm{P} 4^{\mathrm{PAS}}$, but not $\mathrm{P} 4^{\mathrm{PL}}$, induced a delay in red halo formation and onset of necrosis in a very similar way to $4^{\mathrm{PAV}}$. With the 0.5 OD agro-inoculum, the necrosis induced by $4^{\mathrm{PAV}}$ or $\mathrm{P} 4^{\mathrm{PAS}}$ was barely discernable to the naked eye at $4 \mathrm{dpi}$ and obvious at $7 \mathrm{dpi}$ (Figure $4 \mathrm{~A}$ top and Figure $4 \mathrm{~B}$ ), and the boundaries of the spots were as devoid of red halos as the $\mathrm{P} 19$ spots. Diluting the $\mathrm{P} 4{ }^{\mathrm{PAV}}$ and $\mathrm{P} 4{ }^{\mathrm{PAS}}$ infiltrate solutions five-fold (Figure 4A bottom and Figure 4B 1:5 dilution), with buffer containing vector-less agrobacterium, led to some halo induction and reduction of necrosis, which indicates a dose-dependent effect by both $\mathrm{P} 4$ proteins on red halo formation and necrosis induction. The five-fold dilution of $\mathrm{P} 4{ }^{\mathrm{PAV}}$ and $\mathrm{P} 4{ }^{\mathrm{PAS}}$ infiltrate solutions also produced a mild increase in GFP fluorescence in infiltrated spots at 4 dpi when compared to the control empty vector, and this difference to the control was still discernable at $7 \mathrm{dpi}$, although less obvious. This mild increase in GFP fluorescence compared to the control was also noted in spots infiltrated with $\mathrm{P} 4^{\mathrm{PL}}$ at $4 \mathrm{dpi}$, but no longer detectable at 5 dpi (Figure $4 \mathrm{~A}$ top and bottom). These results indicate that both $\mathrm{P} 4^{\mathrm{PAV}}$ and $\mathrm{P} 4^{\mathrm{PAS}}$ produce weak and transient local VSR activity, which is even less pronounced in the case of $\mathrm{P} 4^{\mathrm{PL}}$.

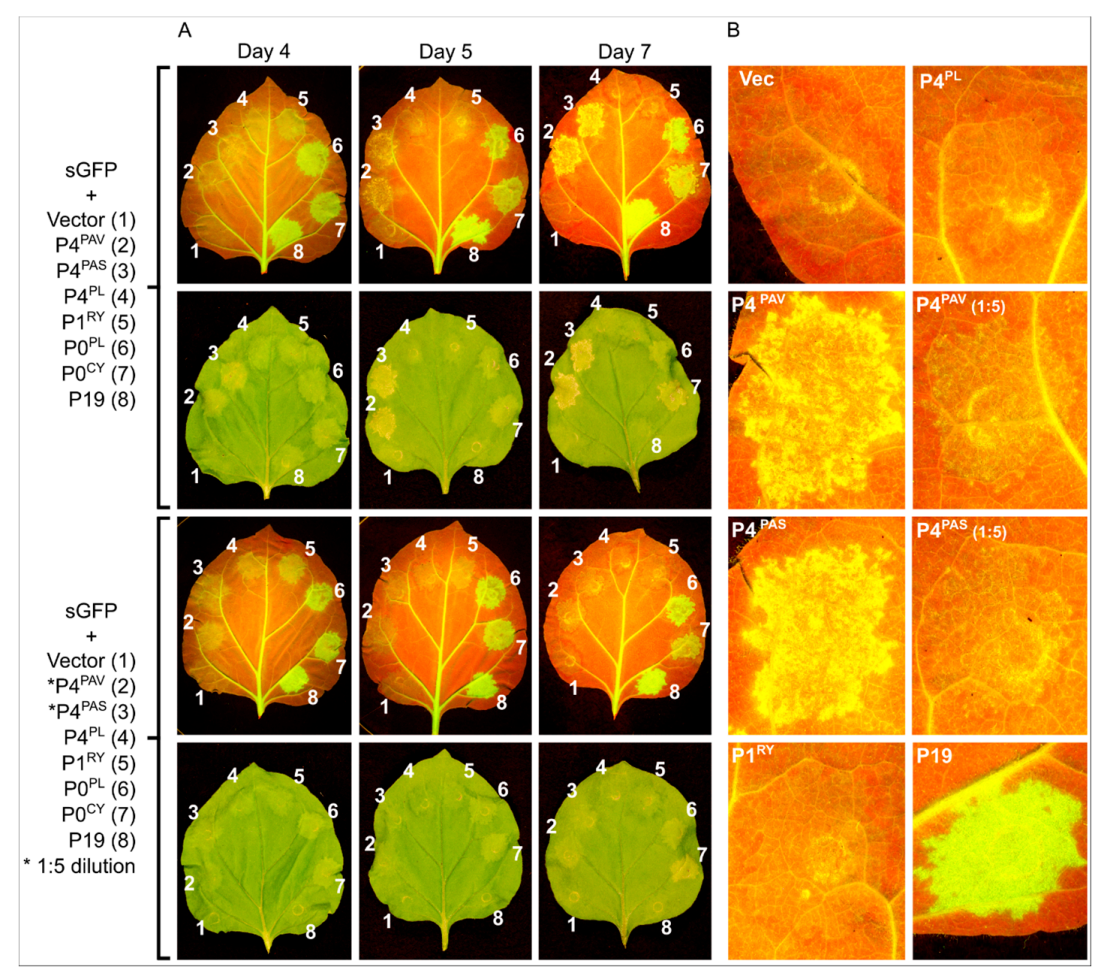

Figure 4. Induction of necrosis by different luteovirus P4 proteins is dose-dependent. Agro-infiltration of GFP-expressing N. benthamiana 16c leaves with sense GFP transgene (sGFP) plus the BYDV-PAV P4 (2), BYDV-PAS P4 (3), PLRV P4 (4) or the control empty pBART vector (1), RYMV P1 (5), PLRV P0 (6), CYDV P0 (7) or TBSV P19 (8) ((A), top panel). Necrosis symptoms were significantly lessened when the P4 from BYDV-PAV and BYDV-PAS was tested at a five-fold dilution (0.1 OD) ((A), bottom panel, see asterisk). Pictures were taken at 4, 5 and 7 dpi under UV or white light. (B) Close-up of selected infiltrations at $7 \mathrm{dpi}$ highlighting that the P4 from BYDV-PAV and BYDV-PAS, but not the P4 from PLRV are able to inhibit the formation of a red halo around the infiltrated area, a hallmark of the cell-to-cell silencing spread. 
Single leaves of young 16c plants were infiltrated with a cocktail of sGFP and one of the P4 or control vectors, and observed for 20 days for the emergence of systemic silencing. $\mathrm{P}^{\mathrm{PAV}}$ and $\mathrm{P} 4^{\mathrm{PAS}}$, but not $\mathrm{P} 4{ }^{\mathrm{PL}}$, gave profiles of strong systemic suppressors (Figure $5 \mathrm{~A}$ ), and this lack of VSR activity by $\mathrm{P} 4{ }^{\mathrm{PL}}$ (Figure 5A,D) could be explained by the low sequence conservation $(\sim 53 \%)$ between the polerovirus $\mathrm{P} 4$ and the two luteovirus P4 proteins which are highly conserved ( 91\% sequence identity) (Figure S1). In this experiment, both $\mathrm{P} 4{ }^{\mathrm{PAV}}$ and $\mathrm{P} 4{ }^{\mathrm{PAS}}$ showed stronger VSR activities than $\mathrm{P}^{\mathrm{RY}}$, and using different agro-infiltrate concentrations of the $\mathrm{P} 4$ constructs revealed that $\mathrm{P} 4{ }^{\mathrm{PAS}}$ is slightly weaker than $\mathrm{P} 4{ }^{\mathrm{PAV}}$ (Figure 5B,C), with their systemic VSR activities being dose-dependent.

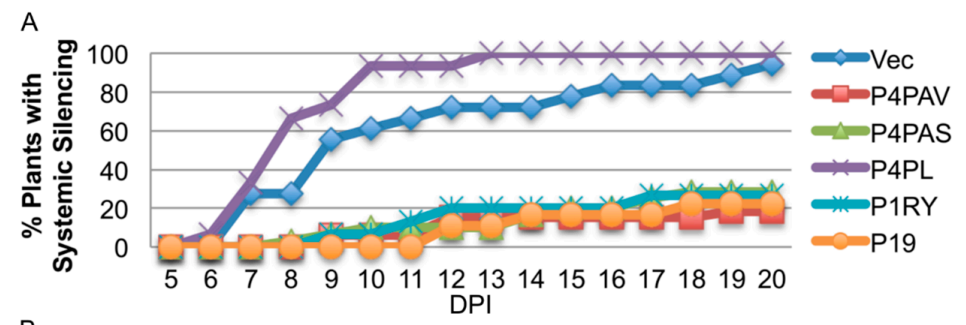

B
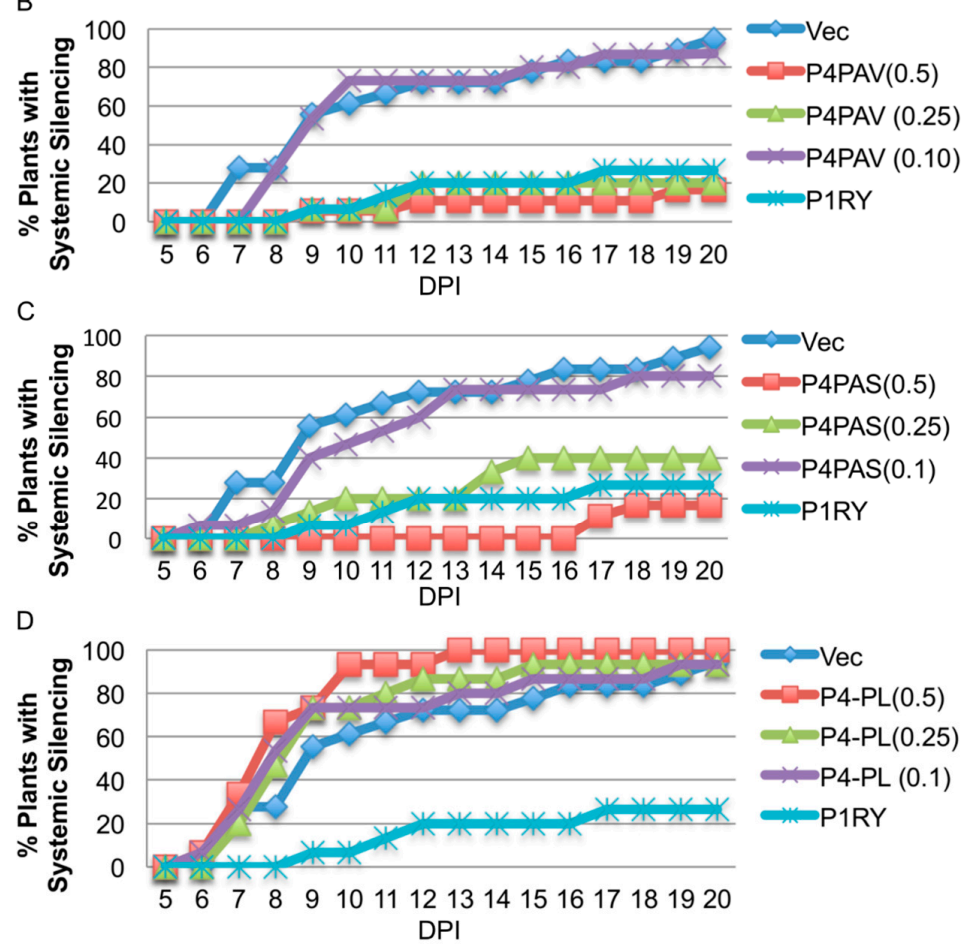

Figure 5. Dose-dependent systemic silencing suppression activities of the luteovirus P4 proteins. N. benthamiana 16c plants were agro-infiltrated with a sense GFP transgene plus the empty vector (vec), BYDV-PAV P4 (P4PAV), BYDV-PAS P4 (P4PAS), PLRV P4 (P4PL), RYMV P1 (P1RY) or TBSV P19. Percentage of plants showing systemic silencing was scored at different days post-infiltration (DPI). (A) Agro-infiltration of 0.5 OD cultures of all candidate suppressor proteins. (B) Agro-infiltration of 0.5, 0.25 or 0.1 OD cultures of P4PAV. (C) Agro-infiltration of $0.5,0.25$ or 0.1 OD cultures of P4PAS (D) Agro-infiltration of $0.5,0.25$ or 0.1 OD cultures of P4PL. The empty vector, P19 and P1RY at 0.5 OD were used as negative and positive controls.

\section{4. $P 4^{P A V}$ and $P 4^{P A S}$ Reduce the Production or Accumulation of siRNAs}

To investigate the mechanism of the systemic VSR activity of $\mathrm{P}^{\mathrm{PAV}}$ and $\mathrm{P} 4{ }^{\mathrm{PAS}}$, the production of siRNAs was measured by Northern blots. Agroinfiltration of 16c plants with the 35S:GFP transgene is known to induce the production of siRNAs against the GFP mRNA by an RNA-dependent RNA polymerase-mediated process and these secondary siRNAs guide the destruction of the GFP 
mRNA [42,43]. Total RNA extracts were made from 16c leaves infiltrated with different cocktails of agrobacterium cultures containing constructs for the expression of GFP and candidate or control VSR genes, and collected at $6 \mathrm{dpi}$. The RNA extracts were size fractionated, run on gels, transferred to membranes and probed with the 300-nt 3' sequence of the GFP gene. The blots (Figure 6) show that the GFP mRNA level dropped from its endogenous level (16c) in tissues infiltrated with the 35S:GFP transgene $(\mathrm{Vec})$ and became elevated in leaf tissues co-infiltrated with the transgene and $\mathrm{P} 19$ or $\mathrm{P} 0 \mathrm{PL}$. Tissues co-infiltrated with $35 \mathrm{~S}$ :GFP and $\mathrm{P} 1^{\mathrm{RY}}, \mathrm{P} 4^{\mathrm{PAS}}$, or $\mathrm{P} 4^{\mathrm{PL}}$ showed GFP mRNA levels similar to those of the GFP transgene alone. Interestingly, $\mathrm{P}^{\mathrm{PAV}}$-infiltrated tissues had slightly increased GFP mRNA accumulation, which could be almost nullified by a five-fold dilution of the $\mathrm{P} 4{ }^{\mathrm{PAV}}$ agro-inoculum

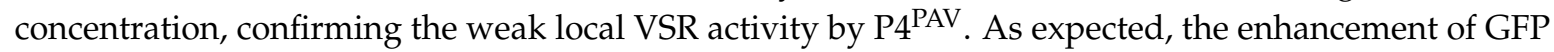
mRNA levels by P19 and P0 were mirrored by reduced levels of GFP-specific siRNAs. This is consistent with their local VSR activities, since P19 affects siRNA stability and production, while P0 affects the production of siRNAs [12,20,44,45]. The siRNA levels of all size classes were also considerably reduced in the tissues infiltrated with $\mathrm{P} 4{ }^{\mathrm{PAV}}$ and $\mathrm{P} 4{ }^{\mathrm{PAS}}$, with a minor reduction in tissues treated with $\mathrm{P} 4{ }^{\mathrm{PL}}$ or the diluted $\mathrm{P} 4{ }^{\mathrm{PAV}}$ inoculum.

The visible GFP fluorescence of $4^{\mathrm{PAV}}$ and $\mathrm{P}^{\mathrm{PAS}}$ infiltrated leaves (Figure 6) and the GFP mRNA levels in samples taken from them (Figure 6, GFP mRNA blot) were not greatly elevated, unlike those treated with $\mathrm{P} 19$ or P0. However, the GFP-specific siRNAs in the P4 ${ }^{\mathrm{PAV}}$ and $\mathrm{P} 4{ }^{\mathrm{PAS}}$ samples were nearly as low as in the P19 or P0 treated samples (Figure 6, siRNA blot). This suggests that systemic VSR activities of $\mathrm{P} 4{ }^{\mathrm{PAV}}$ and $\mathrm{P} 4{ }^{\mathrm{PAS}}$ are related to their capacity to reduce the local production or accumulation of secondary siRNAs, which could be explained, in part, by their weak local VSR activities. However, $\mathrm{P} 4{ }^{\mathrm{PAV}}$ and $\mathrm{P} 4{ }^{\mathrm{PAS}}$ probably operate differently to either $\mathrm{P} 19$ or $\mathrm{P} 0$ since they lack strong local silencing suppression activity. The different increase in GFP mRNA accumulation at 6 dpi (Figure 6, GFP mRNA blot) confirms that $\mathrm{P}^{\mathrm{PAS}}$ is slightly weaker than $\mathrm{P}^{\mathrm{PAV}}$ in its VSR activity.

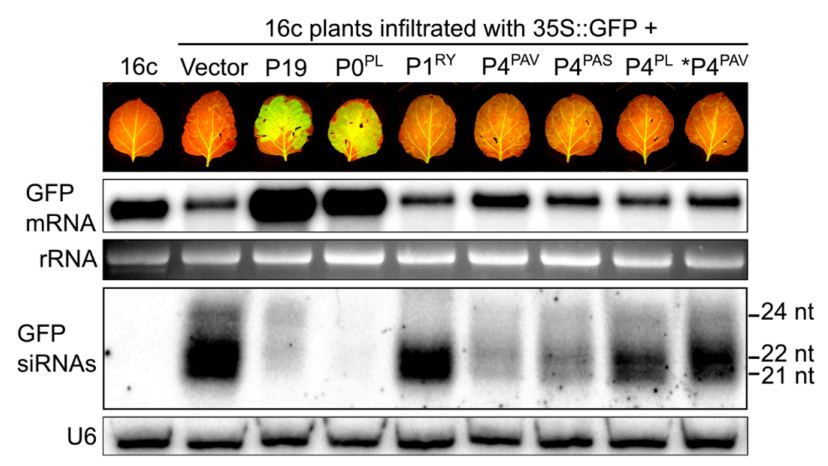

Figure 6. $\mathrm{P} 4^{\mathrm{PAV}}$ and $\mathrm{P} 4^{\mathrm{PAS}}$ reduce the accumulation of siRNAs. GFP-expressing N. benthamiana 16c leaves were co-infiltrated with sense GFP plus the empty vector, TBSV P19, PLRV P0 (P0 $\left.{ }^{\mathrm{PL}}\right)$ or RYMV $\mathrm{P} 1\left(\mathrm{P} 1^{\mathrm{RY}}\right)$ as controls, or BYDV-PAV P4 $\left(\mathrm{P}^{\mathrm{PAV}}\right)$, BYDV-PAS P4 $\left(\mathrm{P} 4^{\mathrm{PAS}}\right)$ or PLRV P4 $\left(\mathrm{P} 4^{\mathrm{PL}}\right) . \mathrm{P}^{\mathrm{PAV}}$ was also infiltrated at a five-fold dilution $\left({ }^{*} \mathrm{P} 4{ }^{\mathrm{PAV}}\right)$. Non-infiltrated plants $(16 \mathrm{c})$ were also included as negative controls. Pictures were taken under the UV light and leaf samples collected for Northern blots at 6 dpi. Total RNA $(20 \mu \mathrm{g})$ was blotted and probed for the presence of GFP mRNA. rRNA was used as a loading control for high-molecular-weight RNA. Total RNA $(40 \mu \mathrm{g})$ from the agro-infiltrated tissues was also blotted and probed for the presence of GFP siRNAs. U6 was used as a loading control for low-molecular weight RNA. RNA size markers are indicated.

\subsection{Induction of Cell Death by $P 4^{P A V}$ and $P 4^{P A S}$ Does Not Prevent Viral Replication and Spread}

As both BYDV and the only other described luteovirus, bean leafroll virus, are known to induce phloem necrosis in their hosts [46-48], it is possible that the P4s of these viruses could be the elicitors of this response. This suggests that these viruses would have evolved to not only fight the anti-viral silencing machinery but to also escape from cells undergoing host-induced cell death in the vasculature. 
For this to be true, the virus has to replicate and egress from the infected cell before the cell dies from necrotic processes induced by $\mathrm{P} 4$.

To test whether the processes induced by $\mathrm{P} 4{ }^{\mathrm{PAV}}$ and $\mathrm{P} 4{ }^{\mathrm{PAS}}$ might allow viral replication and spread to occur before the death of infected cells, a PVX-GFP infectious clone was agroinfiltrated in various combinations with the $\mathrm{P} 4$ and control constructs into wild-type $N$. benthamiana leaves using the concentrations that induce the cell death response. As expected, agroinfiltration of the PVX-GFP construct with $\mathrm{P} 4{ }^{\mathrm{PL}}, \mathrm{P} 1^{\mathrm{RY}}$, or vector backbone, which do not induce necrosis, produced PVX-GFP that, at $5 \mathrm{dpi}$, was able to replicate and spread from the infiltration spots to the nearest veins, then pass via the petiole (Figure 7A) to the apex of the plant (Figure 7B). Despite inducing tissue necrosis, the PVX-GFP $/ \mathrm{P} 4^{\mathrm{PAV}}$ and PVX-GFP $/ \mathrm{P} 4^{\mathrm{PAS}}$ infiltrations with agro-inoculum strength of $0.5 \mathrm{OD}$ also generated PVX that was able to spread systemically at this same time point (Figure 7A,B). Moreover, even the co-infiltration of PVX-GFP with a fungal resistance gene (L6), which also induces cell death, allowed PVX to replicate and spread systemically at 6 dpi.

This assay with a GFP-encoding PVX construct also identifies local VSRs, since PVX-GFP replicates to a higher level and expresses its GFP gene more strongly and for longer in the presence of a VSR [20]. The co-infiltration of PVX-GFP with $\mathrm{P}^{\mathrm{PAV}}$ or P4 ${ }^{\mathrm{PAS}}$ constructs led to a slight increase in GFP fluorescence in infiltrated spots when compared to $\mathrm{P} 4^{\mathrm{PL}}, \mathrm{P} 1^{\mathrm{RY}}$, or vector backbone (Figure $7 \mathrm{~A}, \mathrm{C}$ ), which confirms the weak local VSR activity by $\mathrm{P} 4{ }^{\mathrm{PAV}}$ and $\mathrm{P}^{\mathrm{PAS}}$. Although the two luteovirus $\mathrm{P} 4$ proteins did not display strong local silencing suppression activity during PVX replication when compared to $\mathrm{P0} 0^{\mathrm{PL}}, \mathrm{P0} \mathrm{Cr}^{\mathrm{CY}}$ and $\mathrm{P} 19$ (Figure $7 \mathrm{C}$ ), the replicated virus was still able to exit before the death of the infected cell, induced by $\mathrm{P} 4$.

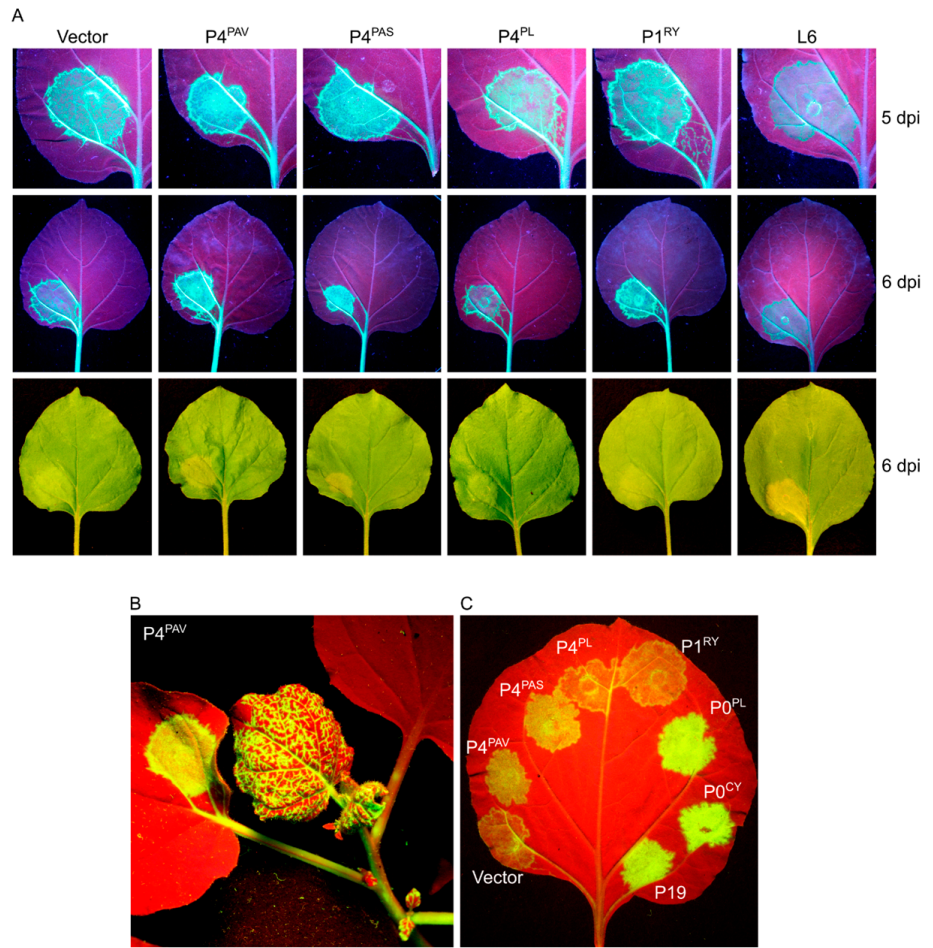

Figure 7. Effects of necrosis induced by luteovirus P4 on virus replication and spread. (A) Wild-type N. benthamiana plants were infiltrated with PVX tagged with GFP (PVX-GFP) plus empty vector (vector), BYDV-PAV P4 (P4 $\left.{ }^{\mathrm{PAV}}\right)$, BYDV-PAS P4 (P4 $\left.{ }^{\mathrm{PAS}}\right)$, PLRV P4 $\left(\mathrm{P} 4{ }^{\mathrm{PL}}\right), \mathrm{RYMV} \mathrm{P} 1\left(\mathrm{P} 1^{\mathrm{RY}}\right)$ or the fungal resistance gene L6. Pictures were taken either under UV or normal light at 5 and 6 days post-infection (dpi). (B) Systemic spread of PVX-GFP co-infiltrated with $\mathrm{P} 4{ }^{\mathrm{PAV}}$ at 5 dpi. (C) Local silencing suppression assay by co-infiltration of PVX-GFP with the empty vector, $\mathrm{P} 4^{\mathrm{PAV}}, \mathrm{P} 4^{\mathrm{PAS}}, \mathrm{P} 4^{\mathrm{PL}}, \mathrm{P} 1^{\mathrm{RY}}, \mathrm{PLRV} \mathrm{P0}\left(\mathrm{P} 0^{\mathrm{PL}}\right)$, CYDV P0 (P0 $\left.{ }^{\mathrm{CY}}\right)$ or the TBSV P19. 


\section{Discussion}

RNA silencing is the main anti-viral mechanism in plant tissues and the viral counter-defence usually involves avoidance or inactivation of the mechanism. As a survival strategy, the P0 proteins of some poleroviruses and the enamovirus have been reported to be strong local VSRs, acting by destabilizing AGO1 [20,44,45,49,50]. The viruses of the family Luteoviridae are strongly associated with the phloem tissues of their host plants [51], and the possession of strong locally-acting VSRs by the enamovirus and the poleroviruses might suggest that cells of the vasculature possess highly active RNA silencing machinery. The levels of virus-derived siRNAs detected by deep-sequencing PLRV- and cotton leafroll dwarf virus-infected materials (representing $15 \%$ and $6 \%$ of total sRNAs, respectively) support this [52,53]. However, the luteovirus BYDV-PAV replicates in cereals to similarly high levels as the polerovirus cereal yellow dwarf virus (CYDV)-RPV [33], and its siRNA profile revealed that it too is attacked by the RNA silencing machinery (this report). Yet, BYDV-PAV does not have an ORF in a counterpart genomic location to the enamovirus or poleroviruses, and testing all of the proteins expressed from the genome failed to identify any strong locally-acting VSR.

A feature of BYDV-PAV that is not shared with poleroviruses is the production of a highly abundant subgenomic RNA3. It seemed possible that BYDV-PAV, in lieu of a strong locally-acting VSR, might express this non-coding RNA as a decoy for the RNA silencing machinery. CaMV has been shown to use such a strategy, producing an RNA from the leader sequence of its $35 \mathrm{~S}$ transcript that attracts the plant's siRNA generating machinery [54]. However, despite sgRNA3 accumulating to levels approaching 100-fold higher than the genomic RNA [33], there was not a dramatic overabundance of siRNAs produced from this genomic region. This shows that either sgRNA3 does not play this role or acts by augmenting the number of RNAs that AGO must scan within the cell, thus quenching its activity.

Remarkably, the protein previously identified as a movement protein, encoded by BYDV-PAV ORF 4, suppressed the spread of the silencing signal in N. benthamiana assays; a capacity also displayed by BYDV-PAS P4, but not polerovirus PLRV P4. The systemic VSR activity by the two luteovirus P4 proteins was accompanied by a reduced production of local siRNAs and a delay in the short-distance spread of the silencing signal, and these effects were dose-dependent. The systemic VSR activity by $\mathrm{P} 0$ proteins of the poleroviruses PLRV $\left(\mathrm{PO}^{\mathrm{PL}}\right), \mathrm{CYDV}\left(\mathrm{P0} 0^{\mathrm{CY}}\right)$ and sugarcane yellow leaf virus $\left(\mathrm{P}^{\mathrm{SC}}\right)$ and the enamovirus PEMV-1 $\left(\mathrm{P} 0^{\mathrm{PE}}\right)$ also induce similar effects, although they also have strong local VSR activity [20,49]. In the case of P0s, the destabilization of AGO1 provides a mechanism for the suppression of systemic spread of the silencing signal, since AGO1 appears to be required for systemic silencing $[20,42,55,56]$. Because luteoviruses lack an F-box-like $\mathrm{P} 0$ protein, it is possible that $\mathrm{P} 4{ }^{\mathrm{PAV}}$ and $\mathrm{P} 4{ }^{\mathrm{PAS}}$ operate differently to $\mathrm{P} 0$ to reduce the production or accumulation of siRNAs and suppress systemic silencing. The lack of strong local VSR activity by $\mathrm{P} 4{ }^{\mathrm{PAV}}$ and $\mathrm{P} 4{ }^{\mathrm{PAS}}$ compared to polerovirus and enamovirus P0s also supports this hypothesis. The degree of systemic silencing suppression by $\mathrm{P}^{\mathrm{PAV}}$ and ${ }^{\mathrm{P}} 4^{\mathrm{PAS}}$ was similar to RYMV P1, which is another example of a movement protein with effective systemic VSR activity and very weak local silencing suppression, but its suppression mechanism still remains largely unknown $[57,58]$.

The expression of $\mathrm{P}^{\mathrm{PAV}}$ and $\mathrm{P}^{\mathrm{PAS}}$ in $N$. benthamiana elicits a response by the plant that leads to cell death in the infiltrated tissues, and the degree of necrosis directly correlates with P4 titers. Similar observations were recently reported for BYDV P4 [59]. Different poleroviral P0 proteins $\left(\mathrm{P} 0^{\mathrm{PL}}, \mathrm{P}^{\mathrm{CY}}\right.$, $\mathrm{P} 0^{\mathrm{SC}}$ and beet western yellows virus $\mathrm{P} 0$ ) have also been reported to trigger necrosis in infiltrated tissues $[20,49]$. It could be hypothesised that $\mathrm{P} 4{ }^{\mathrm{PAV}}$ and $\mathrm{P} 4^{\mathrm{PAS}}$ caused the infiltrated cells to die before the sGFP construct could be transcribed to high levels and before secondary siRNAs could be amplified from GFP mRNA, which would explain the low levels of GFP siRNAs in these tissues (Figure 6) and the reduction in red halo formation (Figures 3 and 4). However, the inhibition of necrosis in infiltrated tissues, by concomitantly expressing the antiapoptotic protein CED-9 with P4 ${ }^{\mathrm{PAV}}$ (Figures 3 and S2), did not affect the $\mathrm{P} 4^{\mathrm{PAV}}$ VSR activities of delaying the short-distance movement of the silencing signal (seen as reduced red halo) and displaying strong suppression of systemic silencing, nor did 
it significantly increase GFP fluorescence in the infiltrated spots. This suggests that the VSR activity displayed by $\mathrm{P} 4^{\mathrm{PAV}}$ and $\mathrm{P} 4^{\mathrm{PAS}}$ on the reduction of secondary siRNA production or accumulation is independent of the necrotic process.

Luteoviruses are known to induce phloem necrosis in their hosts and it is possible that the P4 protein of these viruses could act as elicitors of this response. Nevertheless, the necrosis triggered by luteovirus P4 in infiltrated tissues did not inhibit P4's systemic VSR activity against the propagation and spread of anti-viral siRNAs, nor did it prevent the replication and egress of PVX. Although lacking a strong local silencing suppressor, the strong systemic VSR activity by BYDV-PAV P4 and BYDV-PAS $\mathrm{P} 4$ and the weaker VSR activity by $\mathrm{P} 6{ }^{\mathrm{PAV}}$, suggest that suppression of systemic silencing is the principal mechanism by which the luteoviruses BYDV-PAV and BYDV-PAS minimize the effects of the plant's anti-viral defense.

Supplementary Materials: The following are available online at www.mdpi.com/1999-4915/9/10/294/s1, Figure S1: Phylogenetic analysis of Luteovirus P6 proteins and luteovirid P4 proteins, Figure S2: Local systemic silencing assay with BYDV-PAV proteins P4 and P6.

Acknowledgments: This work was carried out with funding from the Australian Research Council to Peter M. Waterhouse and from the Brazilian agencies FAPERJ, CNPq and CAPES to Regis L. Correa.

Author Contributions: Adriana F. Fusaro, Maite F. S. Vaslin, Regis L. Correa and Peter M. Waterhouse conceived and designed the experiments; Adriana F. Fusaro, Deborah A. Barton, Kenlee Nakasugi, Craig Jackson, Melanie L. Kalischuk, Lawrence M. Kawchuk and Regis L. Correa performed the experiments; Adriana F. Fusaro, Maite F. S. Vaslin, Regis L. Correa and Peter M. Waterhouse analyzed the data; Lawrence M. Kawchuk, Regis L. Correa and Peter M. Waterhouse contributed reagents/materials/analysis tools; Adriana F. Fusaro, Regis L. Correa and Peter M. Waterhouse wrote the paper.

Conflicts of Interest: The authors declare no conflict of interest.

\section{References}

1. Llave, C. Virus-derived small interfering RNAs at the core of plant-virus interactions. Trends Plant Sci. 2010, 15, 701-707. [CrossRef] [PubMed]

2. Bouche, N.; Lauressergues, D.; Gasciolli, V.; Vaucheret, H. An antagonistic function for Arabidopsis DCL2 in development and a new function for DCL4 in generating viral siRNAs. EMBO J. 2006, 25, 3347-3356. [CrossRef] [PubMed]

3. Deleris, A.; Gallego-Bartolome, J.; Bao, J.; Kasschau, K.D.; Carrington, J.C.; Voinnet, O. Hierarchical action and inhibition of plant Dicer-like proteins in antiviral defense. Science 2006, 313, 68-71. [CrossRef] [PubMed]

4. Fusaro, A.F.; Matthew, L.; Smith, N.A.; Curtin, S.J.; Dedic-Hagan, J.; Ellacott, G.A.; Watson, J.M.; Wang, M.-B.; Brosnan, C.; Carroll, B.J.; et al. RNA interference-inducing hairpin RNAs in plants act through the viral defence pathway. EMBO Rep. 2006, 7, 1168-1175. [CrossRef] [PubMed]

5. Donaire, L.; Wang, Y.; Gonzalez-Ibeas, D.; Mayer, K.F.; Aranda, M.A.; Llave, C. Deep-sequencing of plant viral small RNAs reveals effective and widespread targeting of viral genomes. Virology 2009, 392, 203-214. [CrossRef] [PubMed]

6. Garcia-Ruiz, H.; Takeda, A.; Chapman, E.J.; Sullivan, C.M.; Fahlgren, N.; Brempelis, K.J.; Carrington, J.C. Arabidopsis RNA-dependent RNA polymerases and dicer-like proteins in antiviral defense and small interfering RNA biogenesis during Turnip Mosaic Virus infection. Plant Cell 2010, 22, 481-496. [CrossRef] [PubMed]

7. Blevins, T.; Rajeswaran, R.; Shivaprasad, P.V.; Beknazariants, D.; Si-Ammour, A.; Park, H.-S.; Vazquez, F.; Robertson, D.; Meins, F.; Hohn, T.; et al. Four plant Dicers mediate viral small RNA biogenesis and DNA virus induced silencing. Nucleic Acids Res. 2006, 34, 6233-6246. [CrossRef] [PubMed]

8. Carbonell, A.; Carrington, J.C. Antiviral roles of plant ARGONAUTES. Curr. Opin. Plant. Biol. 2015, 27, 111-117. [CrossRef] [PubMed]

9. Wang, X.-B.; Wu, Q.; Ito, T.; Cillo, F.; Li, W.-X.; Chen, X.; Yu, J.-L.; Ding, S.-W. RNAi-mediated viral immunity requires amplification of virus-derived siRNAs in Arabidopsis thaliana. Proc. Natl. Acad. Sci. USA 2010, 107, 484-489. [CrossRef] [PubMed]

10. Csorba, T.; Kontra, L.; Burgyán, J. Viral silencing suppressors: Tools forged to fine-tune host-pathogen coexistence. Virology 2015, 479-480, 85-103. [CrossRef] [PubMed] 
11. Burgyan, J.; Havelda, Z. Viral suppressors of RNA silencing. Trends Plant Sci. 2011, 16, 265-272. [CrossRef] [PubMed]

12. Lakatos, L.; Csorba, T.; Pantaleo, V.; Chapman, E.J.; Carrington, J.C.; Liu, Y.P.; Dolja, V.V.; Calvino, L.F.; Lopez-Moya, J.J.; Burgyan, J. Small RNA binding is a common strategy to suppress RNA silencing by several viral suppressors. EMBO J. 2006, 25, 2768-2780. [CrossRef] [PubMed]

13. Zhang, X.; Yuan, Y.-R.; Pei, Y.; Lin, S.-S.; Tuschl, T.; Patel, D.J.; Chua, N.-H. Cucumber mosaic virus-encoded $2 \mathrm{~b}$ suppressor inhibits Arabidopsis Argonaute1 cleavage activity to counter plant defense. Genes Dev. 2006, 20, 3255-3268. [CrossRef] [PubMed]

14. Haas, G.; Azevedo, J.; Moissiard, G.; Geldreich, A.; Himber, C.; Bureau, M.; Fukuhara, T.; Keller, M.; Voinnet, O. Nuclear import of CaMV P6 is required for infection and suppression of the RNA silencing factor DRB4. EMBO J. 2008, 27, 2102-2112. [CrossRef] [PubMed]

15. Brault, V.; Bergdoll, M.; Mutterer, J.; Prasad, V.; Pfeffer, S.; Erdinger, M.; Richards, K.E.; Ziegler-Graff, V. Effects of point mutations in the major capsid protein of beet western yellows virus on capsid formation, virus accumulation, and aphid transmission. J. Virol. 2003, 77, 3247-3256. [CrossRef] [PubMed]

16. Lee, L.; Kaplan, I.B.; Ripoll, D.R.; Liang, D.; Palukaitis, P.; Gray, S.M. A surface loop of the potato leafroll virus coat protein is involved in virion assembly, systemic movement, and aphid transmission. J. Virol. 2005, 79, 1207-1214. [CrossRef] [PubMed]

17. Schmitz, J.; Stussi-Garaud, C.; Tacke, E.; Prufer, D.; Rohde, W.; Rohfritsch, O. In situ localization of the putative movement protein (pr17) from potato leafroll luteovirus (PLRV) in infected and transgenic potato plants. Virology 1997, 235, 311-322. [CrossRef] [PubMed]

18. Smirnova, E.; Firth, A.E.; Miller, W.A.; Scheidecker, D.; Brault, V.; Reinbold, C.; Rakotondrafara, A.M.; Chung, B.Y.W.; Ziegler-Graff, V. Discovery of a Small Non-AUG-Initiated ORF in Poleroviruses and Luteoviruses That Is Required for Long-Distance Movement. PLoS Pathog. 2015, 11. [CrossRef] [PubMed]

19. Brault, V.; Perigon, S.; Reinbold, C.; Erdinger, M.; Scheidecker, D.; Herrbach, E.; Richards, K.; Ziegler-Graff, V. The polerovirus minor capsid protein determines vector specificity and intestinal tropism in the aphid. J. Virol. 2005, 79, 9685-9693. [CrossRef] [PubMed]

20. Fusaro, A.F.; Correa, R.L.; Nakasugi, K.; Jackson, C.; Kawchuk, L.; Vaslin, M.F.; Waterhouse, P.M. The Enamovirus P0 protein is a silencing suppressor which inhibits local and systemic RNA silencing through AGO1 degradation. Virology 2012, 426, 178-187. [CrossRef] [PubMed]

21. Larkin, M.A.; Blackshields, G.; Brown, N.P.; Chenna, R.; Mcgettigan, P.A.; McWilliam, H.; Valentin, F.; Wallace, I.M.; Wilm, A.; Lopez, R.; et al. Clustal W and Clustal X version 2.0. Bioinformatics 2007, 23, 2947-2948. [CrossRef] [PubMed]

22. Tamura, K.; Peterson, D.; Peterson, N.; Stecher, G.; Nei, M.; Kumar, S. MEGA5: Molecular evolutionary genetics analysis using maximum likelihood, evolutionary distance, and maximum parsimony methods. Mol. Biol. Evol. 2011, 28, 2731-2739. [CrossRef] [PubMed]

23. Langmead, B.; Trapnell, C.; Pop, M.; Salzberg, S.L. Ultrafast and memory-efficient alignment of short DNA sequences to the human genome. Genome Biol. 2009, 10, R25. [CrossRef] [PubMed]

24. Li, H.; Handsaker, B.; Wysoker, A.; Fennell, T.; Ruan, J.; Homer, N.; Marth, G.; Abecasis, G.; Durbin, R. The Sequence Alignment/Map format and SAMtools. Bioinformatics 2009, 25, 2078-2079. [CrossRef] [PubMed]

25. Haseloff, J.; Siemering, K.R.; Prasher, D.C.; Hodge, S. Removal of a cryptic intron and subcellular localization of green fluorescent protein are required to mark transgenic Arabidopsis plants brightly. Proc. Natl. Acad. Sci. USA 1997, 94, 2122-2127. [CrossRef] [PubMed]

26. Lindbo, J.A. High-efficiency protein expression in plants from agroinfection-compatible Tobacco mosaic virus expression vectors. BMC Biotechnol. 2007, 7, 52. [CrossRef] [PubMed]

27. Howles, P.; Lawrence, G.; Finnegan, J.; McFadden, H.; Ayliffe, M.; Dodds, P.; Ellis, J. Autoactive alleles of the flax L6 rust resistance gene induce non-race-specific rust resistance associated with the hypersensitive response. Mol. Plant. Microb. Interact. 2005, 18, 570-582. [CrossRef] [PubMed]

28. Dickman, M.B.; Park, Y.K.; Oltersdorf, T.; Li, W.; Clemente, T.; French, R. Abrogation of disease development in plants expressing animal antiapoptotic genes. Proc. Natl. Acad. Sci. USA 2001, 98, 6957-6962. [CrossRef] [PubMed]

29. Gleave, A.P. A versatile binary vector system with a T-DNA organisational structure conducive to efficient integration of cloned DNA into the plant genome. Plant Mol. Biol. 1992, 20, 1203-1207. [CrossRef] [PubMed] 
30. Coutu, C.; Brandle, J.; Brown, D.; Brown, K.; Miki, B.; Simmonds, J.; Hegedus, D.D. PORE: A modular binary vector series suited for both monocot and dicot plant transformation. Transgenic Res. 2007, 16, 771-781. [CrossRef] [PubMed]

31. Ruiz, M.T.; Voinnet, O.; Baulcombe, D.C. Initiation and maintenance of virus-induced gene silencing. Plant Cell 1998, 10, 937-946. [CrossRef] [PubMed]

32. Rakotondrafara, A.M.; Polacek, C.; Harris, E.; Miller, W.A. Oscillating kissing stem-loop interactions mediate $5^{\prime}$ scanning-dependent translation by a viral 3'-cap-independent translation element. RNA 2006, 12, 1893-1906. [CrossRef] [PubMed]

33. Kelly, L.; Gerlach, W.L.; Waterhouse, P.M. Characterisation of the subgenomic RNAs of an Australian isolate of barley yellow dwarf luteovirus. Virology 1994, 202, 565-573. [CrossRef] [PubMed]

34. Pérez-Cañamás, M.; Blanco-Pérez, M.; Forment, J.; Hernández, C. Nicotiana benthamiana plants asymptomatically infected by Pelargonium line pattern virus show unusually high accumulation of viral small RNAs that is neither associated with DCL induction nor RDR6 activity. Virology 2017, 501, 136-146. [CrossRef] [PubMed]

35. Voinnet, O.; Vain, P.; Angell, S.; Baulcombe, D.C. Systemic spread of sequence-specific transgene RNA degradation in plants is initiated by localized introduction of ectopic promoterless DNA. Cell 1998, 95, 177-187. [CrossRef]

36. Voinnet, O.; Lederer, C.; Baulcombe, D.C. A viral movement protein prevents spread of the gene silencing signal in Nicotiana benthamiana. Cell 2000, 103, 157-167. [CrossRef]

37. Liu, Y.; Zhai, H.; Zhao, K.; Wu, B.; Wang, X. Two suppressors of RNA silencing encoded by cereal-infecting members of the family Luteoviridae. J. Gen. Virol. 2012, 93, 1825-1830. [CrossRef] [PubMed]

38. Dunoyer, P.; Himber, C.; Voinnet, O. DICER-LIKE 4 is required for RNA interference and produces the 21-nucleotide small interfering RNA component of the plant cell-to-cell silencing signal. Nat. Genet. 2005, 37, 1356-1360. [CrossRef] [PubMed]

39. Dunoyer, P.; Himber, C.; Ruiz-Ferrer, V.; Alioua, A.; Voinnet, O. Intra- and intercellular RNA interference in Arabidopsis thaliana requires components of the microRNA and heterochromatic silencing pathways. Nat. Genet. 2007, 39, 848-856. [CrossRef] [PubMed]

40. Smith, L.M.; Pontes, O.; Searle, I.; Yelina, N.; Yousafzai, F.K.; Herr, A.J.; Pikaard, C.S.; Baulcombe, D.C. An SNF2 protein associated with nuclear RNA silencing and the spread of a silencing signal between cells in Arabidopsis. Plant Cell 2007, 19, 1507-1521. [CrossRef] [PubMed]

41. Xu, P.; Rogers, S.J.; Roossinck, M.J. Expression of antiapoptotic genes bcl-xL and ced-9 in tomato enhances tolerance to viral-induced necrosis and abiotic stress. Proc. Natl. Acad. Sci. USA 2004, 101, 15805-15810. [CrossRef] [PubMed]

42. Himber, C.; Dunoyer, P.; Moissiard, G.; Ritzenthaler, C.; Voinnet, O. Transitivity-dependent and -independent cell-to-cell movement of RNA silencing. EMBO J. 2003, 22, 4523-4533. [CrossRef] [PubMed]

43. Luo, Z.; Chen, Z. Improperly terminated, unpolyadenylated mRNA of sense transgenes is targeted by RDR6-mediated RNA silencing in Arabidopsis. Plant Cell 2007, 19, 943-958. [CrossRef] [PubMed]

44. Baumberger, N.; Tsai, C.H.; Lie, M.; Havecker, E.; Baulcombe, D.C. The Polerovirus silencing suppressor P0 targets ARGONAUTE proteins for degradation. Curr. Biol. 2007, 17, 1609-1614. [CrossRef] [PubMed]

45. Bortolamiol, D.; Pazhouhandeh, M.; Marrocco, K.; Genschik, P.; Ziegler-Graff, V. The Polerovirus F box protein P0 targets ARGONAUTE1 to suppress RNA silencing. Curr. Biol. 2007, 17, 1615-1621. [CrossRef] [PubMed]

46. Esau, K. Phloem Degeneration in Gramineae Affected by the Barley Yellow-Dwarf Virus. Source Am. J. Bot. 1957, 44, 245-251. [CrossRef]

47. Adams, M.J.; Antoniw, J.F. DPVweb: A comprehensive database of plant and fungal virus genes and genomes. Nucleic Acids Res. 2006, 34, D382-D385. [CrossRef] [PubMed]

48. Thottappilly, G.; Kao, Y.-C.; Hooper, G.R.; Bath, J.E. Host Range, Symptomatology, and Electron Microscopy of a Persistent, Aphid-Transmitted Virus from Alfalfa in Michigan. Phytopathology 1977, 67, 1451-1459. [CrossRef]

49. Mangwende, T.; Wang, M.L.; Borth, W.; Hu, J.; Moore, P.H.; Mirkov, T.E.; Albert, H.H. The P0 gene of Sugarcane yellow leaf virus encodes an RNA silencing suppressor with unique activities. Virology 2009, 384, 38-50. [CrossRef] [PubMed] 
50. Csorba, T.; Lozsa, R.; Hutvagner, G.; Burgyan, J. Polerovirus protein P0 prevents the assembly of small RNA-containing RISC complexes and leads to degradation of ARGONAUTE1. Plant J. 2010, 62, 463-472. [CrossRef] [PubMed]

51. Ryabov, E.V.; Fraser, G.; Mayo, M.A.; Barker, H.; Taliansky, M. Umbravirus gene expression helps potato leafroll virus to invade mesophyll tissues and to be transmitted mechanically between plants. Virology 2001, 286, 363-372. [CrossRef] [PubMed]

52. Silva, T.F.; Romanel, E.A.; Andrade, R.R.; Farinelli, L.; Osteras, M.; Deluen, C.; Correa, R.L.; Schrago, C.E.; Vaslin, M.F. Profile of small interfering RNAs from cotton plants infected with the polerovirus Cotton leafroll dwarf virus. BMC Mol. Biol. 2011, 12, 40. [CrossRef] [PubMed]

53. Hwang, Y.T.; Kalischuk, M.; Fusaro, A.F.; Waterhouse, P.M.; Kawchuk, L. Small RNA sequencing of Potato leafroll virus-infected plants reveals an additional subgenomic RNA encoding a sequence-specific RNA-binding protein. Virology 2013, 438, 61-69. [CrossRef] [PubMed]

54. Blevins, T.; Rajeswaran, R.; Aregger, M.; Borah, B.K.; Schepetilnikov, M.; Baerlocher, L.; Farinelli, L.; Meins, F., Jr.; Hohn, T.; Pooggin, M.M. Massive production of small RNAs from a non-coding region of Cauliflower mosaic virus in plant defense and viral counter-defense. Nucleic Acids Res. 2011. [CrossRef] [PubMed]

55. Schwach, F.; Vaistij, F.E.; Jones, L.; Baulcombe, D.C. An RNA-dependent RNA polymerase prevents meristem invasion by potato virus $X$ and is required for the activity but not the production of a systemic silencing signal. Plant Physiol. 2005, 138, 1842-1852. [CrossRef] [PubMed]

56. Jones, L.; Keining, T.; Eamens, A.; Vaistij, F.E. Virus-induced gene silencing of argonaute genes in Nicotiana benthamiana demonstrates that extensive systemic silencing requires Argonaute1-like and Argonaute4-like genes. Plant Physiol. 2006, 141, 598-606. [CrossRef] [PubMed]

57. Voinnet, O.; Pinto, Y.M.; Baulcombe, D.C. Suppression of gene silencing: A general strategy used by diverse DNA and RNA viruses of plants. Proc. Natl. Acad. Sci. USA 1999, 96, 14147-14152. [CrossRef] [PubMed]

58. Sire, C.; Bangratz-Reyser, M.; Fargette, D.; Brugidou, C. Genetic diversity and silencing suppression effects of Rice yellow mottle virus and the P1 protein. Virol. J. 2008, 5, 55. [CrossRef] [PubMed]

59. Ju, J.; Kim, K.; Lee, K.-J.; Lee, W.H.; Ju, H.-J. Localization of Barley yellow dwarf virus Movement Protein Modulating Programmed Cell Death in Nicotiana benthamiana. Plant Pathol. J. 2017, 33, 53-65. [CrossRef] [PubMed] 